\title{
Military Spending, the Peace Dividend, and Fiscal Adjustment
}

\author{
HAMID DAVOODI, BENEDICT CLEMENTS, \\ JERALD SCHIFF, and PETER DEBAERE ${ }^{\star}$
}

This paper decomposes the sources of the peace dividend into global, regional, and country-specific factors, and analyzes their relative importance. It finds that the easing of international and regional tensions and the existence of IMFsupported adjustment programs are systematically related to lower military spending and a higher share of nonmilitary spending in total government outlays. The easing of international tensions and of regional tensions since the end of the Cold War and the existence of IMF-supported adjustment programs account for 66 percent, 26 percent, and 11 percent of the decline in military spending, respectively. Furthermore, fiscal adjustment has implied a larger cut in military spending of countries with IMF-supported programs. [JEL H10, H50, H56]

hanges in international relations and the end of the Cold War continue to stimulate economic research on the determinants of military spending, as well as on the relationship between military spending, other public sector outlays, and private consumption. Perceived or actual reductions in international tensions associated with the end of the Cold War have led to discussions regarding the

"Hamid Davoodi is an Economist and Benedict Clements is Deputy Division Chief in the IMF's Fiscal Affairs Department (Expenditure Policy Division); Jerald Schiff is Division Chief in the European 1 Department (Southern Division 1); and Peter Debaere, who was a summer intern in the Fiscal Affairs Department when this research was initiated, is now an Assistant Professor of Economics at the University of Texas at Austin. The authors wish to thank the editor of Staff Papers, two anonymous referees, Sanjeev Gupta, Daniel Hewitt, Hugo Rodriguez, Gerd Schwartz, and Marijn Verhoeven for comments and suggestions, and Tarja Papavassiliou and Erwin Tiongson for computational assistance. 
magnitude of the "peace dividend" and its use (Gleditsch and others, 1996; Clements, Gupta, and Schiff, 1997; Schiff, Gupta, and Clements, 1998; and Rockoff, 1998). At the same time, the need for fiscal adjustment in many countries has led to an increasing focus on unproductive spending in general, including excessive military spending (Chu and others, 1995; and IMF, 1997).

These studies have identified the peace dividend as the observed reduction in military spending over time. A shortcoming of this approach is that it does not allow one to identify, per se, the change in military spending attributable exclusively to reduced international tensions or other factors reflecting a more peaceful environment. That is, because military spending is determined by a host of factors-including those influencing fiscal policy more generally-identification of the peace dividend can only be done in the context of a model capturing the underlying forces driving variations in military spending, including the easing of international and regional tensions.

The first purpose of this paper is to fill this gap in the literature by measuring the sources of the peace dividend and their relative importance in the context of a more general model describing the determinants of military spending. Building on Hewitt (1991, 1992, and 1993), an analytical framework is presented in which military and overall government spending are determined jointly. The framework is used to decompose sources of the peace dividend into global, regional, and country-specific factors. The global factor is common to all countries and measures the extent of international tensions. This source of the peace dividend is, therefore, defined as the drop in military spending due specifically to the easing of international tensions. The regional source is defined as the drop in a country's military spending due to reductions in regional or local tensions. Finally, country-specific factors comprise both economic and noneconomic variables. The drop in military outlays due to variation in these factors determines the source of the peace dividend that is country specific.

A second contribution of this paper is an assessment of the impact of IMFsupported adjustment programs on military spending. While these issues have been addressed by other authors (De Masi and Lorie, 1989; Abed and others, 1998; Schiff, Gupta, and Clements, 1998; and Gupta, McDonald, and Ruggiero, 1998), they have not done so in the context of an analytical framework describing the determinants of government and military spending more generally. In this paper, a quantitative assessment is provided of the impact of IMF-supported adjustment programs per se on military spending and its share in total government outlays. The framework also allows one to quantify a measure of the peace dividend defined as higher nonmilitary spending as a result of lower military spending. ${ }^{1}$ Other studies have defined the peace dividend in terms of other economic gains from lower military spending, such as higher economic growth and higher private investment (Knight, Loayza, and Villanueva, 1996), higher saving (Russett and Slemrod, 1993), higher social spending (Gupta, McDonald, and Ruggiero, 1998), lower

\footnotetext{
${ }^{1}$ This measure, along with others, has been used in descriptive studies of the peace dividend (Clements, Gupta, and Schiff, 1997; Gupta, McDonald and Ruggiero, 1998).
} 
deficits and tax burdens (De Masi and Lorie, 1989; Lee and Vedder, 1996; Gleditsch and others, 1996; and Clements, Gupta, and Schiff, 1997).

\section{The Analytical Framework}

The analytical framework, based on Hewitt (1991, 1992, and 1993), adopts a public-choice approach for analyzing the relationship between military spending and overall government spending. Defense spending or its output-national security-is, from a country's perspective, a pure public good requiring government provision. The determination of military spending is modeled as a government optimization problem. In particular, the political leadership decides on both overall government spending (the size of the budget) as well as the mix between military and nonmilitary spending.

The welfare function of the leadership is as follows:

$$
W=f(C, M, O, Z),
$$

where

$C=$ private consumption;

$M=$ military spending;

$O=$ nonmilitary government spending; and

$Z=$ state variables.

State variables affect the leadership's choice of the level of military and overall government spending and the relative weights the leadership may place on either type of spending. Overall government spending is given by the following identity:

$$
G=M+O \text {. }
$$

Abstracting from private investment, the economy-wide budget constraint is determined by the available resources in the economy:

$$
G=Y-C A-C,
$$

where $Y$ represents the value of gross domestic product and $C A$ the current account surplus.

To get a simple analytical solution, a Cobb-Douglas specification for equation (1) is assumed, while abstracting from the presence of state variables. Thus,

$$
W=C^{\alpha} M^{\beta} O^{\gamma}
$$

Choices of $M$ and $G$ that maximize equation (4) subject to equations (2) and (3) will result in:

$$
M=\frac{\beta}{\beta+\gamma} G
$$


and

$$
G=\frac{\alpha}{\alpha+\gamma} M+\frac{\gamma}{\alpha+\gamma}(Y-C A)
$$

Equations (5) and (6) show the simultaneous relationship between military spending and overall government spending. Higher military spending will lead to higher overall spending and vice versa. And higher external resources (a lower current account surplus) will increase overall government spending directly and military spending indirectly. Dividing both equations by $Y$ and allowing for the state variables to enter the equations, results in:

$$
\frac{M}{Y}=f_{1}\left(\frac{G}{Y} ; Z\right)
$$

and

$$
\frac{G}{Y}=f_{2}\left(\frac{M}{Y}, \frac{Y-C A}{Y} ; Z\right),
$$

where $f_{1}$ and $f_{2}$ are functions. Equations (7) and (8) form a structural model. The model also indicates that what distinguishes the military spending equation from the overall government spending equation is the role of external current account surplus in determining overall government outlays. In the empirical section of the paper, additional identification restrictions are allowed via the state variables, $Z$.

Solving for $\frac{M}{Y}$ and $\frac{G}{Y}$ in (7) and (8) gives the reduced-form equations:

$$
\frac{M}{Y}=h_{1}\left(-\frac{C A}{Y} ; Z\right)
$$

and

$$
\frac{G}{Y}=h_{1}\left(-\frac{C A}{Y} ; Z\right),
$$

where $h_{1}$ and $h_{2}$ are functions.

\section{The Econometric Model}

In the structural model, equations (7) and (8) are specified in log-linear form as follows:

$$
\begin{gathered}
\log \left(m_{i t}\right)=\alpha_{i}+\alpha_{1} \log \left(y_{i t}\right)+\alpha_{2} C W_{i t}+\alpha_{3} I W_{i t}+\alpha_{4} \log \left(h_{i t}\right)+\alpha_{5} \log \left(r_{i t}\right) \\
+\alpha_{6} I M F_{i t}+\alpha_{7} \log \left(g_{i t}\right)+u_{i t}
\end{gathered}
$$




$$
\begin{aligned}
\log \left(g_{i t}\right)=\beta_{i}+\beta_{1} \log \left(y_{i t}\right) & +\beta_{2} \log \left(u r_{i t}\right)+\beta_{3} \log \left(a g e_{i t}\right)+\beta_{4} c a_{i t}+\beta_{5} I M F_{i t} \\
& +\beta_{6} \log \left(m_{i t}\right)+v_{i t},
\end{aligned}
$$

where

$$
\begin{aligned}
& m \text { = ratio of military spending to GDP, } \\
& y=\text { real per capita GDP, } \\
& C W=\text { civil war (dummy variable), } \\
& I W=\text { international war (dummy variable), } \\
& h=\text { measure of international tensions, } \\
& r \quad=\text { measure of regional tensions, } \\
& I M F=\text { existence of IMF-supported adjustment program } \\
& \text { (dummy variable), } \\
& g \quad=\text { ratio of overall government spending to GDP, } \\
& u r \text { = urbanization ratio, } \\
& \text { age }=\text { old age dependency ratio, } \\
& c a=\text { ratio of external current account surplus to GDP. }{ }^{2}
\end{aligned}
$$

and $u_{i t}$ and $v_{i t}$ are error terms. The subscript (it) for each variable refers to country and time period, respectively, as the paper makes use of a panel data set of countries over time. The structural model (equations (11) and (12)) shows the simultaneity between military spending and overall government spending, as well as the presence of state variables. In equation (11), state variables consist of three dummy variables, real per capita GDP, country-specific factors $\left(\alpha_{i}\right)$, and two distinct measures of military tensions. ${ }^{3}$ The inclusion of the latter two variables, along with the dummy variable representing the existence of an IMF-supported adjustment program, distinguishes this paper from earlier work on determinants of military spending. In equation (12), state variables consist of real per capita GDP, the urbanization ratio, the age dependency ratio, the ratio of current account balance to GDP, country-specific factors $\left(\beta_{i}\right)$, and the IMF dummy variable. These variables are routinely employed in studies of determinants of government size (see Heller and Diamond, 1990; Rodrik, 1996; Hewitt and van Rijckeghem, 1995; and Clements, Rodriguez, and Schwartz, 1998). They also constitute additional restrictions that help econometric identification of the military spending equation from the government spending equation in the structural model. For example, the two measures of military tensions affect overall government spending only to the extent that they affect military spending. Hence, they are entered only in the military spending equation. The same argument applies to the dummy variables for civil and international wars. By contrast, the IMF dummy variable is allowed to affect both types of spending directly since the implementation of an IMF-

\footnotetext{
${ }^{2}$ This variable is not in a logarithmic form, since the current account balance can take on positive or negative values.

${ }^{3}$ The dummy variables for civil and international wars and other variables are explained in the next section of the paper.
} 
supported adjustment program presumably affects both the expenditure level and its composition. This issue is investigated empirically later in the paper.

The reduced form model (equations (9) and (10)) are specified in log-linear form as follows:

$$
\begin{aligned}
\log \left(m_{i t}\right)= & \delta_{i}+\delta_{1} \log \left(y_{i t}\right)+\delta_{2} \log \left(u r_{i t}\right)+\delta_{3} \log \left(a g e_{i t}\right)+\delta_{4} c a_{i t}+\delta_{5} C W_{i t} \\
& +\delta_{6} I W_{i t}+\delta_{7} \log \left(h_{i t}\right)+\delta_{8} \log \left(r_{i t}\right)+\delta_{9} I M F_{i t}+\varepsilon_{i t} \\
\log \left(g_{i t}\right)= & \lambda_{i}+\lambda_{1} \log \left(y_{i t}\right)+\lambda_{2} \log \left(u r_{i t}\right)+\lambda_{3} \log \left(a g e_{i t}\right)+\lambda_{4} c a_{i t}+\lambda_{5} C W_{i t} \\
& +\lambda_{6} I W_{i t}+\lambda_{7} \log \left(h_{i t}\right)+\lambda_{8} \log \left(r_{i t}\right)+\lambda_{9} I M F_{i t}+\eta_{i t},
\end{aligned}
$$

where $\varepsilon_{i t}$ and $\eta_{i t}$ are error terms. All the explanatory variables in equations (13) and (14) are the state variables that appear in the structural model.

\section{The Data}

There are four widely known databases on military spending. These are compiled by the Stockholm International Peace Research Institute (SIPRI), the U.S. Arms Control and Disarmament Agency (ACDA), the International Institute for Strategic Studies (IISS), and the IMF's World Economic Outlook (WEO). These databases suffer from shortcomings related to the confidential nature of military activities as well as the lack of a single broadly accepted definition of military spending. ${ }^{4}$ The annual military expenditure data used in this paper are taken from SIPRI's yearbooks, which apply a consistent definition of military expenditure across countries. The SIPRI definition of military spending includes military pensions, military interest payments, and paramilitary expenditures, but excludes police expenditures. Military aid to other nations is included in the military expenditures of the donor country. The nominal military spending data, denominated in local currency, is divided by the local-currency nominal GDP data from the WEO database to obtain the ratio of military expenditures to GDP. The military spending data, along with data on other variables, form a panel data set of up to 130 countries for the 1972-94 period. Transition economies are not included in the panel data set, however, since either military spending data or other variables are missing or of questionable quality for the period in question. For similar reasons, countries whose boundaries changed over time (for example, Germany and Yemen) are excluded. These restrictions reduce the number of countries to 100; see the Appendix for a list of these countries.

Real per capita GDP and the ratio of the current account balance to GDP are taken from the WEO database. The old age dependency ratio and the degree of urbanization are from the World Bank's Social Indicators database. These variables

${ }^{4}$ See Happe and Wakeman-Linn (1994) and Gupta, McDonald, and Ruggiero (1998) for an analysis of different measures of military spending. The latter documents a downward trend in military spending in the 1990s regardless of the data set used. 
are generally expected to be associated with higher government outlays because higher outlays are needed to support an aging population and provide services for the larger population in urban areas. A negative coefficient is expected for the current account surplus since higher external borrowing can finance higher government spending. The civil war and international war dummy variables were constructed on the basis of Sivard (1993) for the years prior to 1992 and the SIPRI yearbook for the years after 1992.5 For every year each dummy variable takes on the value of one if there is a war and zero otherwise. The data for overall government spending refer to central government spending - taken from the WEO - and divided by GDP to get the ratio of government spending to GDP.

\section{Measuring International Tensions}

Two indicators of international tensions are used to measure the global source of the peace dividend: the so-called Doomsday Clock and the number of nuclear explosions by major nuclear powers. Both indicators vary over time and not across countries, which makes them ideal for the purpose of this paper. The Doomsday Clock measures the number of minutes until "midnight" and is taken from the home page of the Bulletin of Atomic Scientists. ${ }^{6}$ A higher number indicates an easing of international tensions, which is expected to be associated with lower military spending. ${ }^{7}$ Box 1 shows the major events that have caused the resetting of the clock over the 1972-94 period, the period under study. The 1972-94 period is of particular interest for this paper since it represents 50 percent of the occasions that the clock has been reset from June 1947 through June 1998.8 It is, therefore, a period that provides a reasonable test of the Doomsday Clock as a measure of international tensions. The second indicator of international tensions measures the number of nuclear weapon explosions by the five major nuclear powers (the United States, the United Kingdom, France, Russia/the former Soviet Union, and China) in a given year and is taken from the SIPRI yearbook. A lower number indicates an easing of international tensions and is expected to be associated with lower military spending.

The two indicators are highly correlated; the simple correlation coefficient between the two indicators is -0.62 , which is significant at the 1 percent level and has the expected sign. The high, but less-than-perfect, correlation coefficient implies that the two indicators are measuring somewhat different aspects of international tensions. Indeed, the Doomsday Clock is a subjective indicator, reflecting

\footnotetext{
${ }^{5} \mathrm{An}$ international war is distinguished from a civil war by the involvement of more than one country. The quantitative limit for inclusion was set at 1,000 casualties in both cases.

6The address is http://www.bullatomsci.org.

${ }^{7}$ The Bulletin devised the Doomsday Clock, the universal symbol of the nuclear age, in order to mark nuclear danger. The Bulletin was first published in December 1945 and the Doomsday Clock appeared for the first time on the cover of the June 1947 issue of the bulletin. The hands of the clock have been moved forward and backward since 1947, reflecting changes in international tensions and the development of the nuclear age. The hands were moved 16 times from June 1947 through June 1998.

${ }^{8}$ On June 1998, the clock was reset from fourteen minutes to midnight, which was in effect since 1995, to nine minutes to midnight in order to mark the series of nuclear explosions carried out by India and Pakistan in May 1998 and the failure of world diplomacy in arresting nuclear proliferation.
} 


\section{Box 1. Changes in International Tensions According to the Bulletin of Atomic Scientists, 1972-94}

1972: Twelve minutes to midnight. The United States and the Soviet Union sign the first Strategic Arms Limitation Treaty (SALT I) and the Anti-Ballistic Missile Treaty; progress toward SALT II is anticipated.

1974: Nine minutes to midnight. SALT talks reach an impasse. India develops a nuclear weapon.

1980: Seven minutes to midnight. The deadlock in U.S.-Soviet arms talks continues; nationalistic wars and terrorist actions increase; the rift between rich and poor nations grows wider.

1981: Four minutes to midnight. Both superpowers develop more weapons for fighting a nuclear war. Terrorist actions; repression of human rights; conflicts in Afghanistan, Poland, and South Africa add to world tension.

1984: Three minutes to midnight. The arms race accelerates.

1988: Six minutes to midnight. The United States and the Soviet Union sign a treaty to eliminate intermediate-range nuclear forces (INF); superpower relations improve; more nations actively oppose nuclear weapons.

1990: Ten minutes to midnight. (In October 1989, the clock is redesigned to expand the definition of world security.) Democratic movements in Eastern Europe shatter the myth of monolithic communism; the Cold War ends.

1991: Seventeen minutes to midnight. The United States and the Soviet Union sign the longstalled Strategic Arms Reduction Treaty (START) and announce further unilateral cuts in tactical and strategic nuclear weapons.

Source: http://www.bullatomsci.org/clock/doomsdayclock.html

many variables considered by the Bulletin's board of directors when deciding on the exact number of minutes, whereas the second indicator is objective and measures only the number of nuclear explosions. Therefore, each indicator may produce different econometric results and a different magnitude of the global peace dividend.

Reflecting the simple correlation coefficient, the historical evolution of the two indicators shows similar trends, with tensions increasing from 1972 until the mid-1980s, and easing subsequently (Figures 1 and 2). A quadratic time-trend fitted to each indicator clearly shows the change in trends (see also Table 1). The $R$-squared of each fitted relationship is in excess of 0.70 , which indicates that the changing trend in international tensions is statistically significant as well. ${ }^{9}$

Figures 1 and 2 also show the persistence of the two indicators, which is an important aspect of the Cold War: when international tensions are high (low), they tend to remain high (low). This is supported by the fact that the simple correlation coefficient between the Doomsday Clock and its lagged value is 0.90 and between the nuclear explosions and its own lagged value is 0.86 .10

\footnotetext{
${ }^{9}$ The estimated parameters of each quadratic trend are statistically significant at the 1 percent level.

${ }^{10}$ The higher correlation coefficient for the Doomsday Clock is an indication of its construction. As Figure 1 shows, the number of minutes until midnight stays unchanged for a number of years.
} 
Figure 1. Doomsday Clock, 1972-94

Minutes to midnight

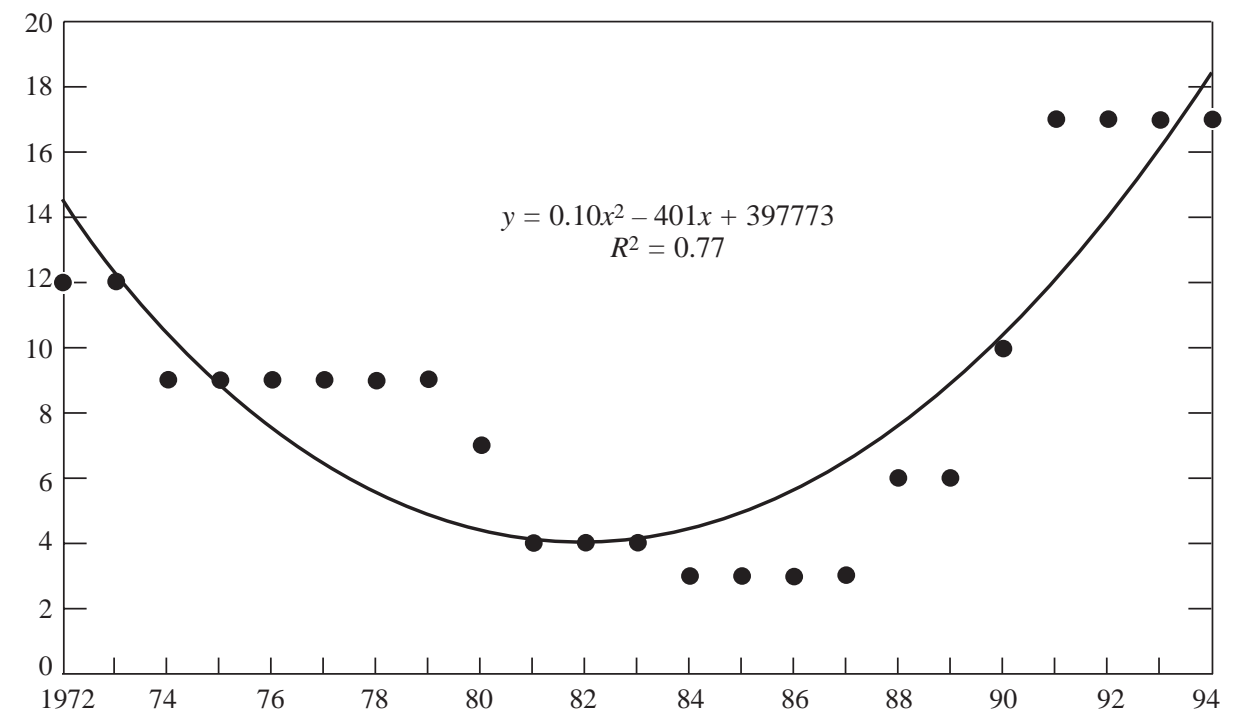

Figure 2. Number of Nuclear Explosions, 1972-94

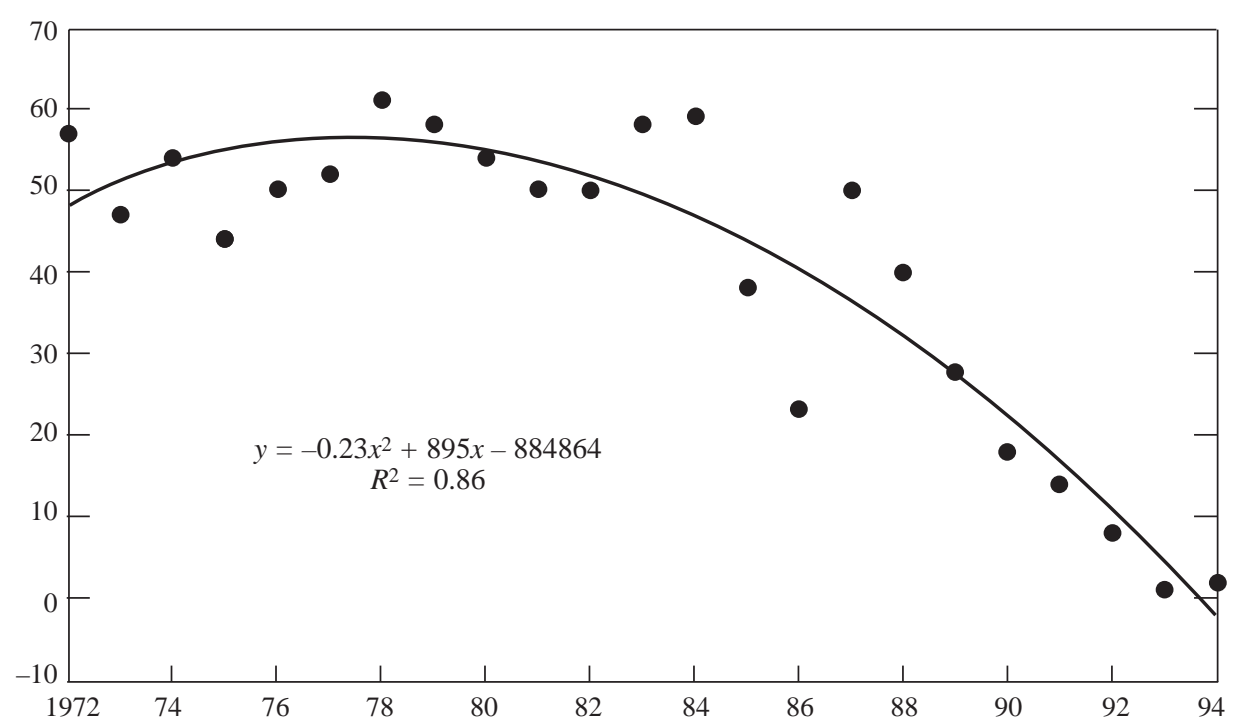




\section{Table 1. Summary Statistics: Measures of Spending and International Tensions \\ (Unweighted average)}

\begin{tabular}{|c|c|c|c|c|c|}
\hline & $1972-94$ & $1972-85$ & 1986-94 & $1972-89$ & $1990-9$ \\
\hline & \multicolumn{5}{|c|}{ Average } \\
\hline \multicolumn{6}{|l|}{ Ratio of military spending } \\
\hline to GDP (in percent) & 4.0 & 4.2 & 3.5 & 4.1 & 3.6 \\
\hline \multicolumn{6}{|l|}{ Neighbors' ratio of military spending } \\
\hline to GDP (in percent) & 4.5 & 4.7 & 4.1 & 4.6 & 3.9 \\
\hline \multicolumn{6}{|l|}{ Ratio of government spending } \\
\hline to GDP (in percent) & 28.0 & 27.5 & 28.9 & 27.7 & 29.2 \\
\hline Doomsday Clock (in minutes) & 8.4 & 7.5 & 10.1 & 6.8 & 15.3 \\
\hline \multirow[t]{2}{*}{ Nuclear explosions (number) } & 41.5 & 52.1 & 22.1 & 48.6 & 9.8 \\
\hline & \multicolumn{5}{|c|}{ Average annual percent change } \\
\hline Ratio of military spending to GDP ${ }^{1}$ & -0.8 & 1.5 & -2.1 & 0.1 & -3.8 \\
\hline Neighbors' ratio of military spending to GDP 1 & -1.5 & 0.7 & -3.1 & -0.6 & -3.0 \\
\hline Ratio of government spending to GDP 1 & 0.9 & 1.6 & 0.4 & 1.1 & 2.1 \\
\hline Doomsday Clock ${ }^{2}$ & 5.5 & -8.9 & 26.3 & -0.9 & 27.3 \\
\hline Nuclear explosions ${ }^{2}$ & -3.8 & -1.8 & -6.7 & 0.3 & -17.7 \\
\hline
\end{tabular}

Sources: WEO; SIPRI; and the Bulletin of Atomic Scientists.

${ }^{1}$ Average annual percent change is obtained by regressing the natural log of the variable on a constant and time trend. Number of observations for the $1972-94$ period is 1,825 .

${ }^{2}$ Averages of year-over-year percent changes.

\section{Measuring Regional Tensions}

Implementation of the model of the previous section requires an indicator of regional tensions, an indicator that is shared by all countries in a given region but distinct from that measuring international tensions. A suitable candidate that satisfies these requirements is the average of the ratio of military spending to GDP of neighboring countries. ${ }^{11}$ For every country, this indicator has been constructed as the unweighted average of military spending to GDP of all countries that share a border with the given country. To our knowledge, this is the first time that such a variable has been constructed and used as a determinant of military spending in an econometric model. ${ }^{12}$ It is intended to measure aspects of the movements in a nation's military spending owing to perceived threats from its neighbors, as

\footnotetext{
${ }^{11}$ Use of regional dummies may be another option, but a dummy variable is merely a measure of one's ignorance about why military spending differs between regions.

${ }^{12}$ The empirical literature on business cycles and economic growth, to name a few, has made use of such variables reflecting strategic complementarities among economic activities, agents, and spillovers across borders. See Cooper and Haltiwagner (1993); Moreno and Trehan (1997); and Easterly and Levine (1998). See also Bayoumi, Hewitt, and Schiff (1995) for a simulation of a large macroeconometric model that demonstrates a significant positive externality from a coordinated reduction in military expenditures across the globe.
} 
Figure 3. Military Spending

Percent of GDP

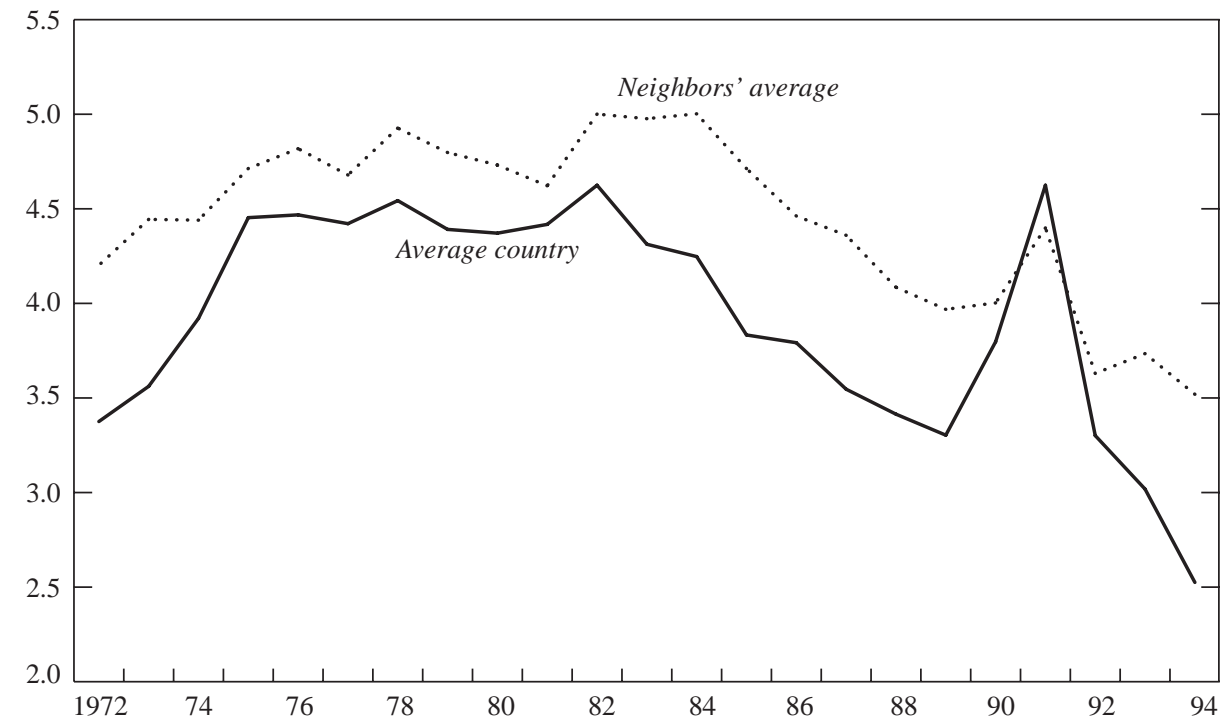

distinct from those owing to the escalation of the arms race between the major nuclear powers. In fact, the data assembled here reveal that there is little correlation between international and regional tensions, and that they are indeed separate influences. ${ }^{13}$ The evolution of military spending and neighbors' military spending is shown in Figure 3. The two closely track each other with a Gulf War-inspired increase in spending in the late 1980s, accompanied by a subsequent decline. By contrast, government spending shows an upward trend in the post-1990 period (Figure 4). The implied increase in nonmilitary spending after 1990 may represent the peace dividend, as some studies have assumed, but it may also be due to other factors that are not related to or caused by lower military spending.

\section{Measuring the Existence of IMF-Supported Programs}

The IMF dummy variable, which marks the presence of an IMF-supported adjustment program in a country for a given year, was constructed based on the criteria in De Masi and Lorie (1989). ${ }^{14}$ It takes a value of unity if there is a program in a given year and zero otherwise. A country is considered to have a program in a given year if (1) in case of a one-year program, at least six months of the program were in that year; (2) for longer-term programs, if at least five months are covered by the year; or (3) in case a program is terminated and a new program begins in

\footnotetext{
${ }^{13}$ The simple correlation coefficient between the neighbors' military spending to GDP ratio, on the one hand, and the Doomsday Clock and the number of nuclear explosions, on the other, is -0.06 and 0.08 , respectively.

${ }^{14}$ See Hewitt and van Rijckeghem (1995), and Clements, Rodriguez, and Schwartz (1998) for a similar methodology.
} 
Figure 4. Government Spending

\section{Percent of GDP}

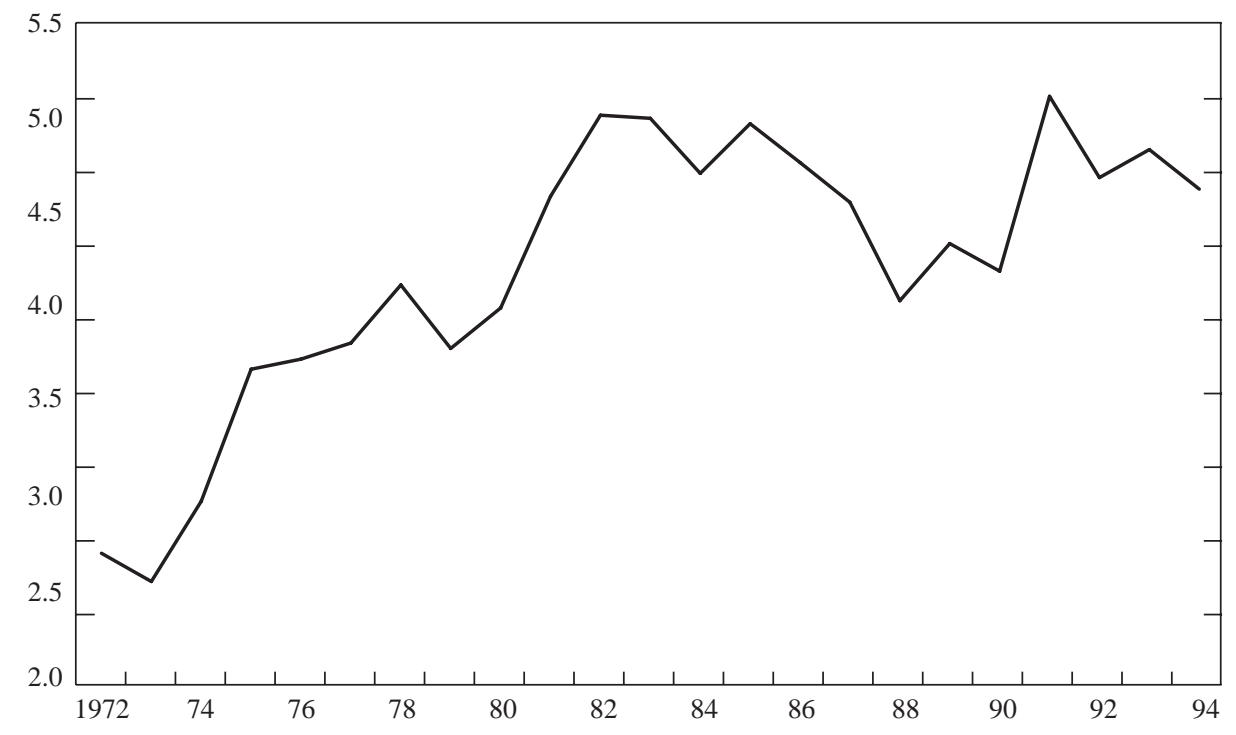

the same year, the total number of months with a program is at least five. It should be noted that measuring the impact of an IMF-supported program with a yearly dummy implicitly assumes that programs have no lasting impact on military or total expenditures. However, the importance of this assumption is mitigated somewhat by the fact that in many countries IMF-supported programs have succeeded one another and some programs last three years.

Figure 5 shows that there is a steady increase in the number of programs throughout the period, rising from a low of 12 in 1975 to a high of 45 in 1994. There were fewer program countries during the 1972-85 period (an average of 23) compared with the 1986-94 period (an average of 34). In the next section, the significance of an IMF-supported adjustment program for explaining movements in military and nonmilitary spending is investigated.

\section{Econometric Results}

The econometric results are based on the structural model (equations (11) and (12)) and the reduced-form model (equations (13) and (14)). The structural model is estimated by the method of Generalized Method of Moments (GMM) and the reduced-form model by ordinary least squares.

\section{Structural Model vs. Reduced-Form Model: An Overview}

The GMM estimation technique is used to address the underlying problems of autocorrelation and heteroskedasticity associated with estimating a structural panel model with endogenous variables. The instruments used in the model are the 
Figure 5. Number of Countries with IMF-Supported Programs

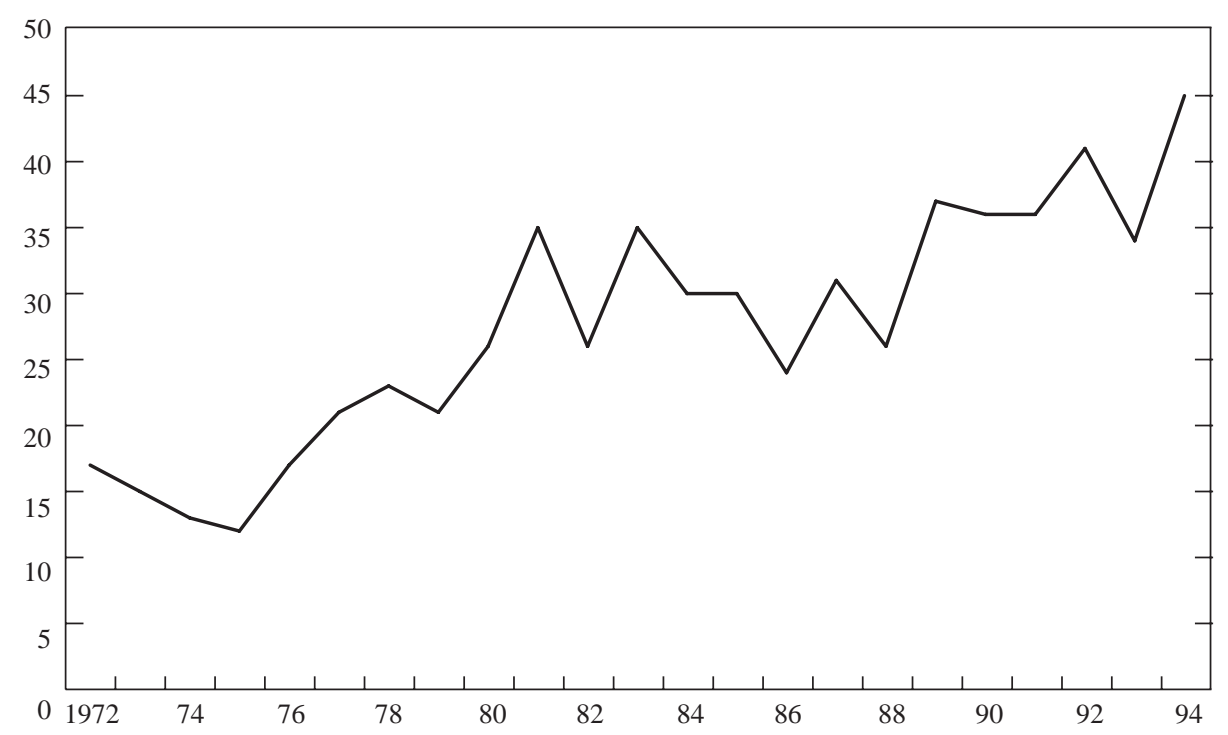

explanatory variables from the reduced form. The comparison of the reduced-form and structural models facilitates an analysis of the direct and indirect influences on the two endogenous variables. In particular, the structural model separates the influences of the exogenous variables on military spending into two channels: an indirect one (via government spending) and a direct one (via the military spending equation). The reduced form provides a convenient summary of the combined effects. Finally, estimation of the structural model with an instrumental variable technique provides point estimates of the response of military spending to exogenous changes in government spending, and the response of government spending to exogenous changes in military spending; and more importantly, it allows one to conduct certain policy analyses that cannot be addressed using the reduced-form model.

For example, the structural model can answer the following question: Does the share of military spending in total government spending fall in response to exogenous contractionary fiscal policy? If the answer is negative, military spending is said to be resilient, whereby reductions in total government spending fall disproportionally on the nonmilitary component of total government spending. Similarly, the structural model can inform the policymaker as to whether the share of nonmilitary spending in total government spending increases in response to exogenous reductions in military spending.

\section{The Structural Model}

The structural model (equations (11) and (12)) is estimated using the two different measures of international tensions: the Doomsday Clock and number of nuclear explosions. Regressions are estimated on demeaned data using as instruments all 
the variables that show up in the reduced form of the model plus a constant. The instruments are: a constant, real per capita GDP, old age dependency ratio, urbanization ratio, ratio of current account to GDP, civil war dummy, international war dummy, the Doomsday Clock, number of nuclear explosions, neighbor's ratio of military spending to GDP, and IMF program dummy. ${ }^{15}$ Results are shown in Table 2. Sargan's test shows that the null hypothesis of the validity of instruments (for example, their exogeneity) is not rejected at the 1 or 5 percent level. The easing of international tensions is associated with reductions in military spending. ${ }^{16}$ The estimated coefficients on the Doomsday Clock and number of nuclear explosions are statistically significant at the 5 percent and 1 percent level, respectively. Military spending is more responsive to the nuclear explosion measure than to the Doomsday Clock measure. ${ }^{17}$ A 5.5 percent increase in the Doomsday Clock and a 3.8 percent decline in the number of nuclear explosions, which are the observed annual average percent decreases in international tensions during the 1972-94 period, are each associated with a 1.1 percentage point decrease in the military spending to GDP ratio. These estimates are quantitatively important because the average ratio of military spending to GDP during the 1972-94 period was about 4 percent (see Table 1).

Neighbors' military spending, the measure of regional or local tensions, has the expected positive sign. A country spends less on its military if its neighbors also spend less. This indicates that coordinated reductions in military spending have multiplier effects and are beneficial to all countries. This evidence lends support to the view that military spending is a "public bad" with negative externalities and spillovers across borders. It also lends support to the view that when a country is outspending its neighbors to ensure its own security, the result can be more insecurity, as the neighbors increase their military spending for the same reason. The estimated parameters on the neighbors' military spending are statistically significant at the 5 percent and 1 percent level when the measure of international tensions are the Doomsday Clock and the number of nuclear explosions, respectively (Table 2, Columns 1 and 3). A 1.5 percent reduction in neighbors' military spending to GDP ratio, which is the observed average annual decline during the 1972-94 period, is associated with about 0.7 percentage point decline in the military spending to GDP ratio of an average country. Evaluated at the sample average of all observations, these estimates translate into a decline in military spending from an average of 4 percent of GDP to 3.3 percent of GDP. For

\footnotetext{
${ }^{15}$ This is equivalent to including country dummies in the regressions. Using demeaned data allows one not to estimate an additional 100 parameters (that is, number of countries) in the GMM estimation of the simultaneous structural model. Note that between-country regressions were not estimated because the two measures of international tensions vary across time only.

16Using lagged rather than contemporaneous measures of international tensions produces similar results. This is an expected result since the evidence in the second part of section III showed the high persistence of these measures. Further, it is plausible to treat the Doomsday Clock and number of nuclear explosions as exogenous since a majority of countries in the sample are small developing countries (see Appendix) that simply take international tensions as given.

${ }^{17}$ Measurement error is one possible reason for the lower point estimate for the Doomsday Clock. If a variable is measured with error, which could be the case with respect to a survey-based measure of the Doomsday Clock, one would expect the estimated coefficient to be biased toward zero.
} 


\section{Table 2. Structural Model with Two Measures of International Tensions}

\begin{tabular}{|c|c|c|c|c|}
\hline & \multicolumn{2}{|c|}{ Doomsday Clock } & \multicolumn{2}{|c|}{$\begin{array}{c}\text { Number of } \\
\text { Nuclear Explosions }\end{array}$} \\
\hline Independent Variables & $\begin{array}{l}\text { Ratio of } \\
\text { military } \\
\text { spending } \\
\text { to GDP } \\
\text { (1) }\end{array}$ & $\begin{array}{l}\text { Ratio of } \\
\text { government } \\
\text { spending } \\
\text { to GDP } \\
\text { (2) }\end{array}$ & $\begin{array}{c}\text { Ratio of } \\
\text { military } \\
\text { spending } \\
\text { to GDP } \\
\text { (3) }\end{array}$ & $\begin{array}{l}\text { Ratio of } \\
\text { government } \\
\text { spending } \\
\text { to GDP } \\
\text { (4) }\end{array}$ \\
\hline Real per capita GDP & $\begin{array}{l}0.06 * * * \\
(8.61)\end{array}$ & $\begin{array}{l}-0.02 \\
(-1.59)\end{array}$ & $\begin{array}{l}0.05 * * * \\
(5.87)\end{array}$ & $\begin{array}{r}0.33^{1} \\
(0.34)\end{array}$ \\
\hline Urbanization ratio & & $\begin{array}{c}0.13 \\
(1.44)\end{array}$ & & $\begin{array}{c}0.31 \\
(3.65)\end{array}$ \\
\hline Age dependency ratio & & $\begin{array}{l}-0.45^{* * *} \\
(-2.68)\end{array}$ & & $\begin{array}{l}-0.32 * * \\
(-1.96)\end{array}$ \\
\hline Ratio of current account to GDP & & $\begin{array}{c}0.05 \\
(0.69)\end{array}$ & & $\begin{array}{c}0.04 \\
(0.57)\end{array}$ \\
\hline Civil war dummy & $\begin{array}{c}0.05 \\
(1.23)\end{array}$ & & $\begin{array}{c}0.06 \\
(1.48)\end{array}$ & \\
\hline International war dummy & $\begin{array}{c}0.14 \\
(0.80)\end{array}$ & & $\begin{array}{c}0.06 \\
(0.50)\end{array}$ & \\
\hline International tensions & $\begin{array}{l}-0.05^{* *} \\
(-1.85)\end{array}$ & & $\begin{array}{l}0.07 * * * \\
(4.10)\end{array}$ & \\
\hline $\begin{array}{l}\text { Neighbors' ratio of military } \\
\text { spending to GDP }\end{array}$ & $\begin{array}{l}0.10 * * \\
(2.38)\end{array}$ & & $\begin{array}{l}0.12 * * * \\
(2.62)\end{array}$ & \\
\hline IMF program dummy & $\begin{array}{c}-0.03 \\
(-1.20)\end{array}$ & $\begin{array}{l}(0.19)^{1} \\
(0.13)\end{array}$ & $\begin{array}{c}-0.03 \\
(-1.23)\end{array}$ & $\begin{array}{l}-0.47^{1} \\
(-0.32)\end{array}$ \\
\hline Ratio of military spending to GDP & & $\begin{array}{l}0.31 * * * \\
(2.50)\end{array}$ & & $\begin{array}{c}0.06 \\
(0.54)\end{array}$ \\
\hline Ratio of government spending to GDP & $\begin{array}{lc}P & 0.38 \\
& (1.09)\end{array}$ & & $\begin{array}{l}0.98 * * * \\
(2.51)\end{array}$ & \\
\hline Number of observations & 1825 & 1825 & 1825 & 1825 \\
\hline$P$-value & 0.10 & 0.10 & 0.18 & 0.18 \\
\hline
\end{tabular}

Note: Generalized Method of Moments (GMM) is the estimation technique, using demeaned data. Numbers in parentheses denote $t$-statistics, based on heteroskedastic, serial-correlationconsistent standard errors. All variables are in logs except for dummy variables and the ratio of the current account to GDP, which takes on positive and negative values. The instruments consist of a constant and all the right-hand-side variables in the reduced form model. The instrument for the interaction variable is IMF program dummy times lagged government spending. $R$-squared is not a goodness-of-fit statistic in regressions estimated by the instrumental variable technique. The $p$-value refers to test of overidentifying restrictions implied by the exogeneity of instruments.

${ }^{1}$ Multiplied by 100 .

***significant at $1 \%$ level; and ** significant at $5 \%$ level. 
example, the data show that when Chile increased its military spending from 6.7 percent of GDP to 9.2 percent of GDP from 1979 to 1982 , its neighbors increased their military spending on average from 3.8 percent of GDP to 5.9 percent of GDP during the same period.

Military spending in countries with IMF-supported adjustment programs is, on average, one percentage point lower than in countries without IMF programs. However, the point estimate on the IMF dummy variable is not statistically significant at the conventional levels.

The estimated parameter on overall government spending, when the Doomsday Clock is the measure of international tensions (Table 2, Column 1), is less than unity, suggesting that military spending has been resilient over the sample period.18 Stated differently, the share of military spending in overall government spending rises in response to exogenous cuts in government spending. ${ }^{19}$ Government spending has a significant impact on military spending during periods of fiscal adjustment. For example, the average annual decline in the overall government spending to GDP ratio from about 1.6 percent during 1972-85 to 0.4 percent during 1986-94 has resulted in a decline in the military spending to GDP ratio from 2.6 percentage points to 0.6 percentage point. These estimates are important, given the observed average military spending to GDP ratio of 4.2 and 3.6 percent during 1972-85 and 1986-94, respectively. Of course there are other factors, given in the regression, that will increase military spending.

The impact of overall government spending on military spending when the number of nuclear explosions is the measure of international tensions (Table 2, Column 3) is much higher than when the Doomsday Clock is taken as the measure of international tensions. The point estimate of 0.98 is not significantly different from unity, suggesting that the share of military spending in overall government spending does not change in response to exogenous changes in overall government spending. Therefore, the question of resiliency cannot be resolved on the basis of the evidence presented so far. As regards other variables in the regression, wars are expected to lead to higher military spending, and not surprisingly this is the finding in Table 2. Military spending tends to increase with per capita GDP, and the associated point estimate is statistically significant at the 1 percent level.

The regressions with the overall government spending to GDP ratio as the dependent variable (Table 2, Columns 2 and 4) show, as expected, that government outlays tend to increase with the urbanization ratio and higher military spending. ${ }^{20}$ The current account surplus was found not to be statistically significant and did not produce the expected negative sign. The point estimate on military spending is positive and less than unity. This finding suggests that the share of nonmilitary spending in overall government spending increases in response to exogenous reductions in military spending. As regards other variables in the

\footnotetext{
${ }^{18}$ See the next section for further assessment of this issue.

${ }^{19}$ See Franko (1994) for a descriptive analysis of budget-driven cuts in military spending in Latin America.

${ }^{20}$ The ratio of current account to GDP was used since this is consistent with the theoretical model. Results using the ratio of exports and imports to GDP, the variable used by Rodrik (1996), produces a positive coefficient, the same sign as Rodrik's result.
} 
regression, the age dependency ratio has a negative impact on government spending, contrary to what one might expect. A positive coefficient is expected on the old age dependency ratio when the measure of government spending includes general government spending. Because of data availability, however, the measure actually used in the regression is central government spending, which can exclude pension expenditures. The point estimate on per capita GDP changes sign, depending on the measure of international tensions used, thus providing only limited evidence in favor of Wagner's law. ${ }^{21}$ The existence of an IMF-supported program has not generally been associated with lower government outlays, given the statistically insignificant relationship between the IMF dummy variable and government spending. These results are consistent with those of Clements, Rodriguez, and Schwartz (1998) showing that IMF-supported programs have not been associated with reduced government expenditure.

\section{Resiliency of Military Spending}

Previous results provided inconclusive evidence regarding the resiliency of military spending. In addition, regressions did not take into account the fact that resiliency may depend on whether a country has an IMF-supported program. This is an important point since IMF-supported programs invariably seek to ensure the consistency of government spending with the macroeconomic framework, and often attempt to improve the composition of government expenditure. ${ }^{22}$ Hence, the response of military spending to cuts in overall government spending is expected to be different between countries with IMF-supported programs and those without. ${ }^{23}$ To address both issues, an interaction variable, the product of the IMF dummy variable and overall government spending to GDP ratio, is added to the regression in the structural model with the military spending to GDP ratio as the dependent variable. The results are shown in Table 3.

The estimated coefficient on the interaction variable exceeds unity and is statistically significant at the 1 percent level. This finding indicates that the impact of government spending on military expenditure depends on whether a country has an IMF-supported program. The elasticities of military spending with respect to overall government spending, when there is an IMF-supported program, are 1.39 and 1.54, using the Doomsday Clock and the number of nuclear explosions as the measures of international tensions, respectively. The estimated greater-thanunity response shows that, other things being equal, cuts in the government spending to GDP ratio imply a larger cut in the military spending to GDP ratio in countries with IMF-supported programs than in those without such programs. Hence, for countries with IMF-supported programs military spending is not resilient. This finding is consistent with the pattern of fiscal adjustment and military expenditures described in Schiff, Gupta, and Clements (1998). It also indi-

\footnotetext{
${ }^{21}$ Evidence in favor of Wagner's law in the literature is mixed at best; see Easterly and Rebelo (1993); Rodrik (1996); and Commander, Davoodi, and Lee (1997).

${ }^{22}$ See Abed and others (1998).

${ }^{23}$ The presence of an intercept IMF dummy variable cannot address this issue.
} 


\section{Table 3. Structural Model with Two Measures of International Tensions and an Interaction Term}

\begin{tabular}{|c|c|c|c|c|}
\hline \multirow[b]{2}{*}{ Independent Variables } & \multicolumn{2}{|c|}{ Doomsday Clock } & \multicolumn{2}{|c|}{$\begin{array}{c}\text { Number of } \\
\text { Nuclear Explosions }\end{array}$} \\
\hline & $\begin{array}{c}\text { Ratio of } \\
\text { military } \\
\text { spending } \\
\text { to GDP } \\
\text { (1) }\end{array}$ & $\begin{array}{l}\text { Ratio of } \\
\text { government } \\
\text { spending } \\
\text { to GDP } \\
\text { (2) }\end{array}$ & $\begin{array}{l}\text { Ratio of } \\
\text { military } \\
\text { spending } \\
\text { to GDP } \\
\text { (3) }\end{array}$ & $\begin{array}{l}\text { Ratio of } \\
\text { government } \\
\text { spending } \\
\text { to GDP } \\
\text { (4) }\end{array}$ \\
\hline Real per capita GDP & $\begin{array}{l}0.07 * * * \\
(9.67)\end{array}$ & $\begin{array}{l}-0.04 * * * \\
(-3.94)\end{array}$ & $\begin{array}{l}0.07 * * * \\
(7.78)\end{array}$ & $\begin{array}{l}-0.02 * * \\
(-2.13)\end{array}$ \\
\hline Urbanization ratio & & $\begin{array}{c}0.09 \\
(0.94)\end{array}$ & & $\begin{array}{l}0.20^{* *} \\
(2.06)\end{array}$ \\
\hline Age dependency ratio & & $\begin{array}{l}-0.70 * * * \\
(-3.77)\end{array}$ & & $\begin{array}{l}-0.67 * * \\
(-3.81)\end{array}$ \\
\hline Ratio of current account to GDP & & $\begin{array}{c}0.08 \\
(1.02)\end{array}$ & & $\begin{array}{c}0.09 \\
(1.09)\end{array}$ \\
\hline Civil war dummy & $\begin{array}{c}0.04 \\
(0.92)\end{array}$ & & $\begin{array}{c}0.05 \\
(0.94)\end{array}$ & \\
\hline International war dummy & $\begin{array}{c}0.08 \\
(0.34)\end{array}$ & & $\begin{array}{c}0.17 \\
(0.71)\end{array}$ & \\
\hline International tensions & $\begin{array}{l}-0.05^{*} \\
(-1.63)\end{array}$ & & $\begin{array}{c}0.03 \\
(1.53)\end{array}$ & \\
\hline $\begin{array}{l}\text { Neighbors' ratio of military } \\
\text { spending to GDP }\end{array}$ & $\begin{array}{c}0.05 \\
(1.16)\end{array}$ & & $\begin{array}{c}0.07 \\
(1.40)\end{array}$ & \\
\hline IMF program dummy & $\begin{array}{r}0.541 \\
(0.23)\end{array}$ & $\begin{array}{l}(-0.01) \\
(-0.85)\end{array}$ & $\begin{array}{c}0.02 \\
(0.82)\end{array}$ & $\begin{array}{l}-0.02 \\
(-1.60)\end{array}$ \\
\hline Ratio of military spending to GDP & & $\begin{array}{l}0.61^{* * *} \\
(5.13)\end{array}$ & & $\begin{array}{l}0.39^{* * *} \\
(3.82)\end{array}$ \\
\hline Ratio of government spending to GDP & $\begin{array}{l}-0.4 \\
(-0.82)\end{array}$ & & $\begin{array}{l}-0.34 \\
(-0.60)\end{array}$ & \\
\hline $\begin{array}{l}\text { IMF program dummy } \times \text { government } \\
\text { spending-GDP ratio }\end{array}$ & $\begin{array}{l}1.79 * * * \\
(3.72)\end{array}$ & & $\begin{array}{l}1.88^{* * *} \\
(3.39)\end{array}$ & \\
\hline Number of observations & 1740 & 1740 & 1740 & 1740 \\
\hline$P$-value & 0.03 & 0.03 & 0.00 & 0.00 \\
\hline
\end{tabular}

Note: Generalized Method of Moments (GMM) is the estimation technique, using demeaned data. Numbers in parentheses denote $t$-statistics, based on heteroskedastic, serial-correlationconsistent standard errors. All variables are in logs except for dummy variables and the ratio of the current account to GDP, which takes on positive and negative values. The instruments consist of a constant and all the right-hand-side variables in the reduced-form model. The instrument for the interaction variable is IMF program dummy times lagged government spending. $R$-squared is not a goodness-of-fit statistic in regressions estimated by the instrumental variable technique. The $p$-value refers to test of overidentifying restrictions implied by the exogeneity of instruments.

${ }^{1}$ Multiplied by 100 .

*** significant at $1 \%$ level; ** significant at $5 \%$ level; and * significant at 10 percent level. 
cates that countries with IMF-supported programs enjoyed a larger peace dividend, measured in terms of a higher share of nonmilitary spending in overall government spending, than countries without such programs. ${ }^{24}$ IMF-supported programs therefore affect the composition of government spending. For example, the data show that during 1989-93 when Uganda had an IMF-supported program, military spending fell from 2.3 percent of GDP to 1.6 percent of GDP while government spending increased from 13.7 percent of GDP to 20.1 percent of GDP. The data for Uganda also show that during the entire 1972-94 period, government and military spending as a fraction of GDP were lower with IMF-supported programs than without: Ratios of government and military spending to GDP were 24 and 3.5 percent, respectively, with no IMF-supported programs as compared with 16 and 2.1 percent, respectively, with IMF-supported programs.

\section{The Reduced-Form Model}

The reduced-form model, which summarizes the direct effects of the exogenous variables on military spending and the indirect effects exercised through the channel of government spending, provides results that are generally consistent with those obtained from the structural model, but vary in important ways. Results of the reduced-form regressions (equations (13) and (14)) are shown in Table 4. Countries with higher real per capita income, a higher current account surplus, a high degree of urbanization, and a high age dependency ratio tend to have higher military outlays. Unlike the structural model estimates, in the reduced form the civil war variable is significant at the 10 percent level; and much like the structural model, the impact of international wars is positive, but not statistically significant. Reduced international tensions are also associated with lower military outlays using both measures of international tensions. The point estimate for either measure is statistically significant at the 1 percent level.

The reduced-form model shows a larger impact of the easing of international tensions on military spending than the structural model, particularly for the Doomsday Clock measure. Specifically, a 5.5 percent increase in the Doomsday Clock and a 3.8 percent decline in the number of nuclear explosions, which are the same experiments conducted with the structural model, are associated with a 1.5 and 0.9 percentage point decline in the military spending to GDP ratio, respectively.

The reduced form also confirms that the easing of regional tensions, as measured by reductions in neighbors' military spending, is associated with lower military outlays. The magnitude of the impact of neighbors' military spending is considerable. A 1.5 percent reduction in neighbors' military spending to GDP ratio (the observed average annual decline during the 1972-94 period) is associated with a decline in military spending of 0.9 percentage point from 4 percent of GDP to 3.1 percent of GDP. The magnitude of this decline is larger than the decline in

\footnotetext{
${ }^{24}$ This does not imply that countries without any IMF programs did not enjoy any peace dividend, since the structural model and the econometric findings show that there were indeed other sources of the peace dividend, even if the country did not have an IMF-supported program. Also, the peace dividend can manifest itself in terms of economic gains besides higher nonmilitary spending.
} 


\section{Table 4. Reduced-Form Model with Two Measures of International Tensions}

\begin{tabular}{|c|c|c|c|c|}
\hline \multirow[b]{2}{*}{ Independent Variables } & \multicolumn{2}{|c|}{ Doomsday Clock } & \multicolumn{2}{|c|}{$\begin{array}{c}\text { Number of } \\
\text { Nuclear Explosions }\end{array}$} \\
\hline & $\begin{array}{l}\text { Ratio of } \\
\text { military } \\
\text { spending } \\
\text { to GDP } \\
\text { (1) }\end{array}$ & $\begin{array}{l}\text { Ratio of } \\
\text { government } \\
\text { spending } \\
\text { to GDP } \\
\text { (2) }\end{array}$ & $\begin{array}{l}\text { Ratio of } \\
\text { military } \\
\text { spending } \\
\text { to GDP } \\
\text { (3) }\end{array}$ & $\begin{array}{l}\text { Ratio of } \\
\text { government } \\
\text { spending } \\
\text { to GDP } \\
\text { (4) }\end{array}$ \\
\hline Real per capita GDP & $\begin{array}{l}0.06 * * * \\
(8.12)\end{array}$ & $\begin{array}{r}0.58^{1} \\
(1.05)\end{array}$ & $\begin{array}{l}0.05 * * * \\
(5.51)\end{array}$ & $\begin{array}{r}0.63^{1} \\
(1.12)\end{array}$ \\
\hline Urbanization ratio & $\begin{array}{l}0.45 * * * \\
(3.68)\end{array}$ & $\begin{array}{l}0.14 * * \\
(2.09)\end{array}$ & $\begin{array}{l}0.83 * * * \\
(5.23)\end{array}$ & $\begin{array}{l}0.16^{* *} \\
(2.11)\end{array}$ \\
\hline Age dependency ratio & $\begin{array}{c}0.22 \\
(1.18)\end{array}$ & $\begin{array}{l}-0.53 * * * \\
(-4.03)\end{array}$ & $\begin{array}{c}0.08 \\
(0.35)\end{array}$ & $\begin{array}{l}-0.54 * * * \\
(-3.99)\end{array}$ \\
\hline Ratio of current account to GDP & $\begin{array}{c}0.12 \\
(0.93)\end{array}$ & $\begin{array}{c}0.07 \\
(1.00)\end{array}$ & $\begin{array}{c}0.12 \\
(0.96)\end{array}$ & $\begin{array}{c}0.07 \\
(0.95)\end{array}$ \\
\hline Civil war dummy & $\begin{array}{l}0.07 * * \\
(1.74)\end{array}$ & $\begin{array}{c}0.02 \\
(0.46)\end{array}$ & $\begin{array}{l}-0.09 \\
(-1.60)\end{array}$ & $\begin{array}{c}0.02 \\
(0.54)\end{array}$ \\
\hline International war dummy & $\begin{array}{c}0.11 \\
(0.60)\end{array}$ & $\begin{array}{l}0.03 \\
(0.24)\end{array}$ & $\begin{array}{c}-0.02 \\
(-0.10)\end{array}$ & $\begin{array}{c}0.04 \\
(0.35)\end{array}$ \\
\hline International tensions & $\begin{array}{l}-0.07 * * * \\
(-2.99)\end{array}$ & $\begin{array}{l}-0.04 * * * \\
(-3.35)\end{array}$ & $\begin{array}{l}0.06^{* * * *} \\
(4.22)\end{array}$ & $\begin{array}{l}-0.20^{1} \\
(-0.21)\end{array}$ \\
\hline $\begin{array}{l}\text { Neighbors' ratio of military } \\
\text { spending to GDP }\end{array}$ & $\begin{array}{l}0.15 * * * \\
(3.97)\end{array}$ & $\begin{array}{l}-0.791 \\
(-0.28)\end{array}$ & $\begin{array}{l}0.16^{* * * *} \\
(3.65)\end{array}$ & $\begin{array}{c}0.01 \\
(0.36)\end{array}$ \\
\hline IMF program dummy & $\begin{array}{l}-0.03 \\
(-1.46)\end{array}$ & $\begin{array}{l}-0.63^{1} \\
(-0.43)\end{array}$ & $\begin{array}{l}-0.24 * * * \\
(-4.32)\end{array}$ & $\begin{array}{l}-0.46^{1} \\
(-0.31)\end{array}$ \\
\hline Number of observations & 1825 & 1825 & 1825 & 1825 \\
\hline$R$-squared & 0.15 & 0.05 & 0.10 & 0.04 \\
\hline
\end{tabular}

Note: Ordinary least square (OLS) is the estimation technique, using demeaned data. Numbers in parentheses denote $t$-statistics, based on heteroskedastic, serial-correlation-consistent standard errors. All variables are in logs except for the dummy variables and the ratio of current account balance to GDP, which takes on positive and negative values.

${ }^{1}$ Multiplied by 100 .

$* * *$ significant at $1 \%$ level; $* *$ significant at $5 \%$ level; and $*$ significant at 10 percent level.

the structural model (by 0.2 or 0.3 percentage point) for the identical reduction in neighbors' military spending of 1.5 percent. The reduced-form model combines the positive interaction between military spending and overall government spending present in the structural model, and produces a higher elasticity of military spending with respect to neighbors' military spending. Specifically, in the regressions in the structural model with the Doomsday Clock and the number of nuclear explosions as the measures of international tensions, these elasticities are 0.10 and 0.12 , respectively. The corresponding elasticities for the reduced-form model are 0.15 and 0.16 . 
The relative magnitude of the point estimates of both sources of military tensions indicates that reduction in these tensions has increased the share of nonmilitary spending in total government spending. This is consistent with the rise in the ratio of nonmilitary spending to GDP of 2 percentage points from an average of 23.3 percent of GDP during 1972-85 to 25.3 percent of GDP during 1986-94 (see Table 1). This is similar to the increase for the 1972-89 and 1990-94 periods.

As with the structural model, IMF-supported programs, as proxied by an IMF dummy variable, are associated with lower military outlays. The statistical significance of the IMF dummy variable differs according to which measure of international tensions is used in the regression. When the Doomsday Clock is the measure of international tensions, the point estimate on the IMF dummy is significant at the 10 percent level under the one-sided alternative hypothesis that military spending is lower in countries with IMF-supported programs. 25 But when the number of nuclear explosions is the measure of international tensions, the point estimate becomes significant at the 1 percent level using either a one- or two-tail test. The magnitude of the impact of IMF-supported programs is quantitatively important. Other things being equal, military spending in countries with IMF-supported programs is, on average, 1 or 1.3 percent of GDP lower than in countries without such programs. ${ }^{26}$

As regards the government spending regression, results are also consistent with the structural model, including the fragility of Wagner's law, the negative impact of the age dependency ratio, and the insignificance of the current account balance. Countries with IMF-supported programs also have a lower overall government spending to GDP ratio. The point estimates are not statistically significant at the conventional statistical levels, but are quantitatively important. Government spending is, on average, 1 percent of GDP lower in program countries. The average government spending to GDP ratio is 28 percent.

\section{Sources of the Peace Dividend}

As stated earlier, a novelty of this paper is the decomposition of the sources of the peace dividend into global, regional, and country-specific factors. In this regard, this section of the paper answers the following question: How much of the decline in military spending can be attributed to each of these factors? Two time periods are used to calculate the decline in military spending: changes in military spending between 1972-85 and 1986-94 and between 1972-89 and 1990-94. The first time period corresponds to the widely documented decline in military spending that started in 1985 (Hewitt, 1993; Knight, Loayza, and Villanueva, 1996; and Schiff, Gupta, and Clements, 1998); whereas the second period corresponds to the end of the Cold War in 1989, which was also the year the Doomsday Clock was reset to measure the marked decline in international tensions. The point estimates in the reduced-form

\footnotetext{
25The $p$-value associated with this alternative hypothesis is 7 percent.

${ }^{26}$ These are $e^{0.03}$ and $e^{0.24}$, respectively, where 0.03 and 0.24 are the estimated parameters on the IMF dummy variable in Table 4, Columns 1 and 3.
} 
regressions for military spending (Table 4, Columns 1 and 3) are used to quantify the contribution of each factor to the decline in military spending over each of the two periods. The decomposition analysis essentially poses a counterfactual question: How much higher would military spending have been had the international or regional tensions remained as high as those observed before the end of the Cold War?

The results of the decomposition are presented in Table 5 for two measures of international tensions and the two time periods, producing four panels. In each panel, contributions of IMF-supported adjustment programs, neighbors' military spending, and other economic variables to declines in military spending are also shown explicitly. These results can be summarized as follows. First, the decompositions show that the explanatory variables in the reduced-form regressions explain a large fraction of the drop in military spending between the two periods, ranging from a low of 50 percent to a high of 85 percent. Second, the drop in military spending due to the easing of international tensions - the global source of the peace dividend-is quantitatively more important after the end of the Cold War than before. Specifically, the Doomsday Clock explains about 9 percent of the drop in military spending between 1972-85 and 1986-94, but 34 percent of the drop between 1972-89 and 1990-94. The number of nuclear explosions explains about 50 percent of the drop in military spending between 1972-85 and 1986-94, but 66 percent of the drop between 1972-89 and 1990-94. These findings are consistent with the view that the collapse of the former Soviet Union has reduced the role of tensions among its regional "surrogate" nations, since the Soviet Union is no longer there to support its surrogates. Accordingly, the "West" or NATO also feels no need to do the same with its surrogates.

Third, the drop in military spending due to the easing of regional tensionsthe regional source of the peace dividend-is also more important after the end of the Cold War than before. Although the regional source of the peace dividend is not as quantitatively important as the global source, it still accounts for about 23 percent of the drop in military spending. This finding shows that although the Cold War has ended, regional tensions can have the potential of escalating military spending. Fourth, IMF-supported adjustment programs account for up to 11 percent of the drop in military spending between the two periods. ${ }^{27}$ Fifth, economic factors also contribute to changes in military spending. Economic declines have tended to reduce military spending, which is consistent with the findings of Hewitt (1993), whereas the increased trend toward urbanization in developing countries tends to increase these outlays. The net effect varies according to which measure of international tensions is used in the regression.

\section{Conclusions}

This paper has presented evidence that the easing of international and regional tensions is systematically related to subsequent reductions in military spending and the higher share of nonmilitary spending in total spending. The evidence lends

\footnotetext{
${ }^{27}$ IMF programs are not as important when the Doomsday Clock is the measure of international tensions because the estimated parameter on the IMF dummy variable is small and statistically insignificant (Table 4, Column 1).
} 


\section{Table 5. Decomposition of Changes in Military Spending Using Two Measures of International Tensions, by Period (In percent)}

\begin{tabular}{|c|c|c|c|c|}
\hline & \multicolumn{2}{|c|}{$1972-85$ and $1986-94^{1}$} & \multicolumn{2}{|c|}{$1972-89$ and $1990-94^{1}$} \\
\hline & $\begin{array}{l}\text { Average } \\
\text { change }\end{array}$ & $\begin{array}{l}\text { Percent of } \\
\text { actual }\end{array}$ & $\begin{array}{l}\text { Average } \\
\text { change }\end{array}$ & $\begin{array}{l}\text { Percent of } \\
\text { actual }\end{array}$ \\
\hline Actual military spending-GDP & -15.4 & 100.0 & -18.2 & 100.0 \\
\hline \multicolumn{5}{|l|}{ Of which } \\
\hline Doomsday Clock & -1.3 & 8.6 & -6.3 & 34.3 \\
\hline Neighbors' military spending-GDP ratio & -3.7 & 23.7 & -4.5 & 24.5 \\
\hline IMF program dummy & -0.2 & 1.5 & -0.3 & 1.4 \\
\hline Other variables ${ }^{2}$ & -2.7 & 17.7 & -4.5 & 24.8 \\
\hline \multirow[t]{3}{*}{ Unexplained residual } & -7.5 & 48.5 & -2.7 & 14.9 \\
\hline & \multicolumn{2}{|c|}{$1972-85$ and $1986-94^{3}$} & \multicolumn{2}{|c|}{$1972-89$ and $1990-94^{3}$} \\
\hline & $\begin{array}{l}\text { Average } \\
\text { change }\end{array}$ & $\begin{array}{l}\text { Percent of } \\
\text { actual }\end{array}$ & $\begin{array}{l}\text { Average } \\
\text { change }\end{array}$ & $\begin{array}{l}\text { Percent of } \\
\text { actual }\end{array}$ \\
\hline Actual military spending-GDP & -15.4 & 100.0 & -18.2 & 100.0 \\
\hline $\begin{array}{l}\text { Predicted military spending-GDP ratio } \\
\text { Of which }\end{array}$ & -7.7 & 50.2 & -14.5 & 79.4 \\
\hline Nuclear explosions & -7.7 & 50.0 & -12.0 & 65.8 \\
\hline Neighbors' military spending-GDP ratio & -3.9 & 25.3 & -4.8 & 26.2 \\
\hline IMF program dummy & -1.8 & 11.8 & -2.1 & 11.5 \\
\hline Other variables ${ }^{4}$ & 5.7 & -36.9 & 4.4 & -24.1 \\
\hline Unexplained residual & -7.7 & 49.8 & -3.8 & 20.6 \\
\hline
\end{tabular}

${ }^{1}$ Based on the reduced-form regression, Table 4, Column 1, and the data used in the regression.

${ }^{2}$ Sum of contributions from other variables in the regressions given in Table 4, Column 1, besides those listed above.

${ }^{3}$ Based on the reduced-form regression, Table 4, Column 3, and the data used in the regression.

${ }^{4}$ Sum of contributions from other variables in the regressions given in Table 4, Column 3 , besides those listed above.

support to the previous studies of the peace dividend, which simply assumed that improvements in global and regional security will lead to cuts in military spending. In addition, the significance of regional tensions, as proxied by neighbors' military spending, documented the notion that military spending is a public bad; increasing military spending will not necessarily lead to more security for a country since its neighbors are likely to follow the same strategy. The evidence also shows that peace is a public good; mutual reductions in military spending across borders have multiplier effects that are beneficial to all parties concerned.

The second finding of the paper concerned the impact of IMF-supported adjustment programs on military and nonmilitary spending. IMF-supported programs affect the composition of government spending. In countries with IMF programs, the ratio of military spending to GDP is, on average, one percentage 
point smaller than in countries without IMF programs. This is economically important since the average ratio of military spending to GDP is about 4 percent. Cuts in overall government spending imply a larger cut in military spending in countries with IMF-supported programs than in those without such programs.

The third finding of the paper concerned the relative importance of the global and regional sources of the peace dividend as well as the existence of IMFsupported adjustment programs. The easing of international and regional tensions has accounted for up to 66 percent and 26 percent of the decline in military spending respectively; and IMF programs accounted for up to 11 percent of the decline. The remainder is accounted for by other economic factors and an unexplained residual.

It should be pointed out that these decompositions may understate the importance of the two measures of international and regional tensions and overstate the importance of IMF-supported adjustment programs. Owing to a lack of other relevant variables, the sample excluded the transition economies that have witnessed the largest declines in their military spending since the end of the Cold War. In addition, countries involved in an armed conflict typically do not have any IMF programs that will bias the results in favor of a large role for a program. And countries that are not involved in an armed conflict and have an IMF program find it perhaps easier to cut military spending.

The key policy implications of this paper are as follows. Sustained reductions in international and regional tensions would lead to declines in military spending, ensure a more secure world, and achieve a large peace dividend. Different countries would no doubt make different choices about how to utilize the resulting peace dividend. This choice would depend, among other things, upon the nature of political demands on the budget, the geographic location of the country, the nature of military alliances, and the extent of the past defense buildup. These are indeed some reasons that explain why no consensus has so far emerged on the widely posed question, "what happened to the peace dividend?" Furthermore, reducing military spending is important for fiscal adjustment, but fiscal adjustment is also an effective method for reducing military spending, particularly in countries with IMF-supported adjustment programs. In nonprogram countries, fiscal adjustment is possible, but military spending may be resilient to cuts in government spending. Finally, the importance of the regional source of the peace dividend shows that, despite the end of the Cold War, regional tensions have the potential of escalating military spending, jeopardizing the quality of fiscal adjustment, and reducing the magnitude of the peace dividend. 


\section{APPENDIX \\ List of Countries Included in the Paper ${ }^{*}$}

\begin{tabular}{|c|c|c|}
\hline Algeria & Guatemala & Panama \\
\hline Argentina & Guinea-Bissau & Papua New Guinea \\
\hline Austria & Guyana & Paraguay \\
\hline Bangladesh & Haiti & Peru \\
\hline Belgium & Honduras & Portugal \\
\hline Belize & India & Rwanda \\
\hline Benin & Indonesia & Saudi Arabia \\
\hline Bolivia & Iran & Senegal \\
\hline Botswana & Israel & Sierra Leone \\
\hline Brazil & Italy & Somalia \\
\hline Burkina Faso & Jordan & South Africa \\
\hline Burundi & Kenya & Spain \\
\hline Cameroon & Kuwait & Sudan \\
\hline Canada & Lebanon & Swaziland \\
\hline Central African Rep. & Lesotho & Sweden \\
\hline Chad & Liberia & Switzerland \\
\hline Chile & Libya & Syrian Arab Republic \\
\hline China & Luxembourg & Tanzania \\
\hline Colombia & Malawi & Thailand \\
\hline Congo & Malaysia & Togo \\
\hline Costa Rica & Mali & Tunisia \\
\hline Côte d'Ivoire & Mauritania & Turkey \\
\hline Cyprus & Mexico & Uganda \\
\hline Denmark & Morocco & United Arab Emirates \\
\hline Dominican Republic & Mozambique & United Kingdom \\
\hline Ecuador & Myanmar & United States \\
\hline Egypt & Nepal & Uruguay \\
\hline El Salvador & Netherlands & Venezuela \\
\hline Ethiopia & Nicaragua & Viet Nam \\
\hline Finland & Niger & Zaire \\
\hline France & Nigeria & Zambia \\
\hline Gabon & Norway & Zimbabwe \\
\hline Ghana & Oman & \\
\hline Greece & Pakistan & \\
\hline
\end{tabular}

*These countries are referenced in Tables 1, 2, 4, and 5.

\section{REFERENCES}

Abed, George, and others, 1998, Fiscal Reforms in Low-Income Countries: Experience Under IMF-Supported Programs (Washington: International Monetary Fund).

Bayoumi, Tamim, Daniel P. Hewitt, and Jerald Schiff, 1995, "Economic Consequences of Lower Military Spending: Some Simulation Results," in Arms Reduction: Economic Implications in the Post-Cold War, ed. by Lawrence R. Klein, Fu-chen Lo, and Warwick J. McKibbin (New York: United Nations University Press).

Chu, Ke-young, and others, 1995, Unproductive Public Expenditures: A Pragmatic Approach to Policy Analysis, IMF Pamphlet Series, No. 48 (Washington: International Monetary Fund). 
Clements, Benedict, Sanjeev Gupta, and Jerald Schiff, 1997, "What Happened to the Peace Dividend?" Finance and Development, Vol. 34 (March), pp. 17-19.

Clements, Benedict, Hugo Rodriguez, and Gerd Schwartz, 1998, "Economic Determinants of Government Subsidies," IMF Working Paper WP/98/166 (Washington: International Monetary Fund).

Commander, Simon, Hamid R. Davoodi, and Une J. Lee, 1997, "The Causes of Government and the Consequences for Growth and Well-Being," Policy Discussion Paper No. 1785 (Washington: World Bank).

Cooper, R., and J. Haltiwagner, 1993, "Evidence on Macroeconomic Complementarities," NBER Working Paper No. 4577 (Cambridge, Massachusetts: National Bureau of Economic Research).

De Masi, Paula, and Henri Lorie, 1989, "How Resilient Are Military Expenditures?” IMF Staff Papers, Vol. 36, No. 3, pp. 130-65.

Easterly, William, and Sergio Rebelo, 1993, "Fiscal Policy and Economic Growth: An Empirical Investigation,” Journal of Monetary Economics, Vol. 32, No. 3, pp. 417-58.

Easterly, William, and Ross Levine, 1998, "Troubles with the Neighbors: Africa's Problem, Africa's Opportunity," Journal of African Economies, Vol. 7 (March), pp. 120-42.

Franko, Patrice, 1994, "De Facto Demilitarization: Budget-Driven Downsizing in Latin America," Journal of Interamerican Studies and World Affairs, Vol. 36, No. 1, pp. 37-74.

Gleditsch, N. P., and others, eds., 1996, The Peace Dividend (Amsterdam and New York: North-Holland).

Gupta, Sanjeev, Calvin McDonald, and Edgardo Ruggiero, 1998, "Worldwide Military Expenditures Appear to Have Leveled Off," IMF Survey, May, pp. 149-50.

Happe, Nancy, and John Wakeman-Linn, 1994, "Military Expenditure and Arms Trade: Alternative Data Sources," IMF Working Paper WP/94/69 (Washington: International Monetary Fund).

Heller, Peter S., and Jack Diamond, 1990, International Comparisons of Government Expenditure Revisited: The Developing Countries, 1975-86 (Washington: International Monetary Fund).

Hewitt, Daniel P., 1991, "Military Expenditures: Econometric Testing of Economic and Political Influences," IMF Working Paper WP/91/53 (Washington: International Monetary Fund).

—_ 1992, "Military Expenditures Worldwide: Determinants and Trends, 1972-1988," Journal of Public Policy, Vol. 12, No. 2, pp. 105-52.

— 1993, "Military Expenditures 1972-1990: The Reasons Behind the Post-1985 Fall in World Military Spending," IMF Working Paper WP/93/18 (Washington: International Monetary Fund).

— , and Caroline van Rijckeghem, 1995, "Wage Expenditures of Central Governments," IMF Working Paper WP/95/11 (Washington: International Monetary Fund).

International Monetary Fund, 1997, "Reducing Unproductive Expenditures Is Important for Fiscal Adjustment," IMF Survey, February 24, pp. 49-51.

Knight, Malcolm, Norman Loayza, and Delano Villanueva, 1996, “The Peace Dividend: Military Spending Cuts and Economic Growth," IMF Staff Papers, Vol. 43 (March), pp. 1-37.

Lee, Dwight R., and Richard K. Vedder, 1996, "The Political Economy of the Peace Dividend," Public Choice, Vol. 88, Nos. 1-2, pp. 29-42. 
Moreno, Ramon, and Bharat Trehan, 1997, "Location and the Growth of Nations," Journal of Economic Growth, Vol. 2, No. 4, pp. 399-418.

Rockoff, Hugh, 1998, "The Peace Dividend in Historical Perspective," American Economic Review, Papers and Proceedings, Vol. 88, No. 2, pp. 46-50.

Rodrik, Dani, 1996, "Why Do More Open Economies Have Bigger Governments?," NBER Working Paper No. 5537 (Cambridge, Massachusetts: National Bureau of Economic Research).

Russett, Bruce, and Joel Slemrod, 1993, "Diminished Expectations of Nuclear War and Increased Personal Savings: Evidence from Individual Survey Data," American Economic Review, Vol. 83, No. 4, pp. 1022-33.

Schiff, Jerald, Sanjeev Gupta, and Benedict Clements, 1998, "Worldwide Military Spending, 1990-95," Defense and Peace Economics, Vol. 9, No. 3, pp. 237-81.

Sivard, Ruth Leger, 1993, World Military and Social Expenditures (Leesburg, Virginia: WMSE Publications). 